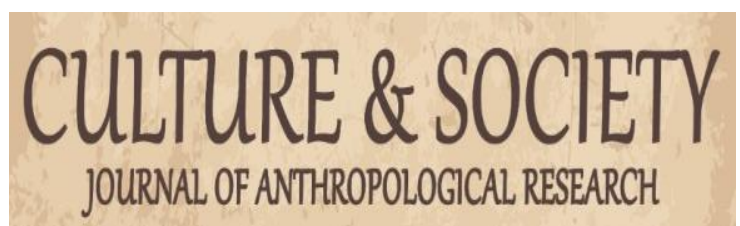

Culture \& Society: Journal of Anthropological Research

VOL. 1 NO. 1 SEPTEMBER 2019

http://culture.ppj.unp.ac.id

Email: culture@ppj.unp.ac.id

ISSN: 2686-343X (E-ISSN) 2686-3421 (P-ISSN)

DOI: https://doi.org/10.24036/culture/vol1-iss1/3

\title{
Konflik Perebutan Harta Warisan Dalam Keluarga Pada Masyarakat Pulau Temiang
}

\author{
Miftahul Jannah ${ }^{1}$, Emizal Amri ${ }^{2}$ \\ ${ }^{1}$ SD Alam Adiba Jambi \\ ${ }^{2}$ Universitas Negeri Padang \\ Email: miftahul.jannah184@yahoo.com, emizalamri@fis.unp.ac.id
}

\begin{abstract}
Abstrak
Penelitian ini bertujuan untuk menggali penyebab dan solusi konflik harta warisan dalam masyarakat Pulau Temiang. Penyelesaian konflik tersebut dilakukan dalam keluarga melalui musyawarah para ahli waris yang disaksikan oleh tokoh adat dan pemerintahan desa. Teori yang dipakai dalam penelitian ini adalah teori konflik dari Lewis A. Coser. Pendekatan dalam penelitian ini adalah kualitatif dengan tipe studi kasus, teknik pemilihan informan yaitu purposive sampling dengan jumlah informan sebanyak 30 orang. Pengumpulan data dilakukan dengan cara observasi partisipasi pasif, wawancara mendalam, dan studi dokumentasi yang dianalisis dengan mengacu pada teknik analisis data yang dikembangkan oleh Miles dan Huberman. Hasil penelitian ini menunjukkan bahwa penyebab terjadinya konflik harta warisan adalah dominasi dari ahli waris tertua dan kecemburuan terhadap perempuan bungsu. Solusi konflik melalui musyawarah keluarga cenderung menyisakan konflik laten (tersembunyi). Putusan yang diberikan tidak bersifat mengikat karena tidak adanya sanksi terhadap pelanggaran terhadap hasil putusan yang diberikan. Selain itu, masyarakat enggan menaikkan kasus ini ke pengadilan negeri karena biaya yang tinggi.
\end{abstract}

Kata Kunci: Konflik, Keluarga, Warisan

\begin{abstract}
This study aims to explore the causes and solutions to conflict over inheritance in the people of Pulau Temiang. The settlement of the conflict is carried out within the family through deliberations of the heirs witnessed by traditional leaders and village government. The theory used in this study is the conflict theory from Lewis A. Coser. The approach in this study is qualitative with the type of case study, the informant selection technique is purposive sampling with the number of informants as many as 30 people. Data collection was carried out by means of passive participation observation, in-depth interviews, and documentation studies that were analyzed by referring to the data analysis techniques developed by Miles and Huberman. The results of this study indicate that the cause of the inheritance conflict is the dominance of the oldest heirs and jealousy towards the youngest woman. Solution to conflict through family consultation tends to leave latent (hidden) conflict. The award rendered is not binding because there are no sanctions for violations of the outcome of the award. In addition, people are reluctant to bring this case to the district court due to high costs.
\end{abstract}

Keywords: Conflict, Family, Inheritance

\begin{tabular}{l|l|l} 
Received: August 29, 2019 & Revised: September 4, 2019 & Published: September 6, 2019 \\
\hline
\end{tabular}

Culture \& Society: Journal of Anthropological Research Vol. 1, No. 1, Th. 2019

2686-343X (E-ISSN) 2686-3421 (P-ISSN) 


\section{Pendahuluan}

Konflik sosial merupakan pertentangan yang terjadi akibat kontak sosial manusia dengan manusia lainnya. Penyebab konflik sosial yaitu faktor kebudayaan, psikologis dan ekonomis. Konflik adalah permasalahan yang ditimbulkan oleh individu dengan individu, individu dengan kelompok, dan kelompok dengan kelompok. (Saputri, Thahar, \& Hayati, 2016). Konflik yang terjadi dalam masyarakat Pulau Temiang merupakan konflik horizontal, yaitu konflik yang terjadi antar ahli waris dalam memperebutkan harta warisan. Harta warisan adalah segala wujud harta kekayaan yang ditinggalkan oleh orang yang telah meninggal dunia setelah dikurangi dengan hutang piutangnya (Titik Khumairoh, 2011). Konflik harta warisan dalam masyarakat Pulau Temiang ini umumnya tidak pernah terselesaikan, terutama karena hanya penyelesaian sementara melalui musyawarah, tidak satupun yang berhasil diselesaikan secara tuntas. Meskipun demikian, Lembaga Adat Melayu (LAM) Jambi sebagai lembaga adat tertinggi penyelesaian kasus peradilan adat tidak dimanfaatkan karena jika menaikkan kasus ke tingkat yang lebih tinggi membutuhkan biaya yang tinggi pula. Hanya 1 (satu) dari 20 kasus yang diselesaikan secara tuntas melalui peradilan negeri. Meskipun perkara harta warisan sudah putus di tingkat desa, tetapi konflik dalam kelurga tetap berlanjut. Konflik yang tampak berupa pertengkaran, salah satu pihak tidak hadir dalam acara keluarga, ada juga yang pindah rumah meninggalkan kampung halaman karena pertengkaran tersebut. Bahkan ada yang sampai meninggal pun salah seorang ahli waris tidak datang untuk menjenguk karena kebencian dalam hal pembagian warisan.

Masyarakat Pulau Temiang menganut sistem kewarisan individual atau perseorangan. Pewarisan merupakan penerusan harta kekayaan yang ditinggalkan oleh pewaris atau perbuatan melakukan pembagian harta warisan kepada ahli warisnya (Arwin Rio Saputra). Pewarisan dengan sistem individual atau perseorangan adalah sistem kewarisan di mana setiap ahli waris mendapatkan pembagian untuk dapat menguasai dan atau memiliki harta warisan menurut bagiannya masing-masing (Mohamad Imam Suhadak, 2015). Sistem pewarisan harta pada masyarakat Pulau Temiang adalah dengan membagi semua harta warisan kepada keturunannya. Harta warisan dibagi sesuai dengan konstribusi anak-anaknya terhadap orangtuanya maupun dengan pertimbangan latar belakang kondisi ekonomi masing-masing pewaris.

Berdasarkan data dari dokumen penelitian, menunjukkan bahwa: pertama, terdapat kecenderungan peningkatan konflik warisan di Pulau Temiang dari tahun ke tahun. Pada tahun 2016 terjadi 5 (lima) kasus, kemudian tahun 2017 terjadi 7 (tujuh) kasus dan pada tahun 2018 (10 bulan) terjadi 8 (delapan) kasus: kedua, dari 20 kasus konflik pewarisan dalam masyarakat setempat hanya 1 (satu) kasus yang berhasil diselesaikan dengan tuntas, yakni melalui pengadilan negeri: ketiga, meskipun konflik pewarisan cenderung meningkat, namun pemuka adat belum menemukan langkah-langkah strategis untuk merespon perubahan yang terjadi secara cepat dan drastis dalam masyarakat setempat. Di pulau temiang justru kasus tersebut diselesaikan melalui musyawarah keluarga.

Penyelesaian konflik ini diselesaikan memalui musyawarah keluarga yang disaksikan oleh ketua adat dan anggota pemerintahan desa. Dalam masyarakat Bangko Jambi sudah sejak lama dikenal penyelesaian konflik secara musyawarah dan mufakat melalui lembaga-lembaga adat seperti peradilan desa atau peradilan adat (Iwan, 2015). Pada masyarakat Pulau Temiang justru kasus harta warisan tersebut diselesaikan melalui musyawarah keluarga.

Dalam masyarakat pulau Temiang, para ahli waris harus menerima hasil putusan adat musyawarah pada saat itu secara adil dan damai, karena dalam adat musyawarah adalah solusi terbaik. Jika tetap berkonflik maka pemuka adat akan mengembalikan kepada pihak-pihak yang berkonflik apakah akan diselesaikan pada tingkat kecamatan, kabupaten, atau melalui pengadilan negeri. Dilihat dari beberapa kasus, penyelesaian konflik hanya sampai pada tingkat desa, meskipun setelah itu konflik tetap muncul kembali.

\section{Culture \& Society: Journal of Anthropological Research Vol. 1, No. 1, Th. 2019}


Sejauh ini penyelesaian konflik pewarisan harta dalam keluarga selalu dilakukan melalui musyawarah dalam keluarga. Musyawarah keluarga ini hanya menekankan kepada bentuk akomodasi harapan dan keinginan sementara, dan tidak ada penyelesaian secara menyeluruh (tuntas). Artinya, penyelesaian yang ditempuh selalu menyisakan permasalahan yang berkepanjangan. Pihak-pihak yang berkonflik hanya menerima putusan musyawarah, tetapi tidak berhasil menyelesaikan permasalahan antar pihak terkait.

\section{Metode Penelitian}

Pendekatan dalam penelitian ini adalah kualitatif. Pendekatan ini bertujuan untuk menghasilkan data deskriptif baik berupa kata-kata tertulis maupun lisan dari orang-orang dan perilaku yang diamati (Lexi J. Moleong, 2000). Melalui pendekatan ini peneliti berpeluang untuk menggali secara detail informasi berkaitan dengan pokok persoalan yang diteliti yaitu tentang konflik harta warisan dalam keluarga pada masyarakat Pulau Temiang yang mengganggu keharmonisan dalam keluarga. Tipe penelitian ini yaitu studi kasus intrinsik tepatnya di Kelurahan Pulau Temiang Kecamatan Tebo Ulu Kabupaten Tebo Provinsi Jambi. Studi kasus intrinsik dilakukan untuk mendapatkan pemahaman yang lebih baik mengenai konflik perebutan harta warisan dalam keluarga di Kelurahan Pulau Temiang.

Pemilihan informan dilakukan dengan teknik-teknik tertentu dengan tujuan untuk menjaring sebanyak mungkin informasi dari berbagai bermacam sumber, serta menggali informasi yang menjadi dasar dari rancangan dan teori yang dibangun. oleh sebab itu, teknik pemilihan informan dilakukan secara purposive sampling dengan jumlah informan sebanyak 30 orang. Tujuannya adalah untuk mengumpulkan data di lapangan yang sesuai dengan kebutuhan dan tujuan penelitian. Peneliti mencari informasi kepada informan dengan cara langsung melihat realita yang ada di lapangan. Peneliti memperhitungkan pengambilan sampel secara purposive untuk dijadikan dasar dalam penentuan medan yang mungkin digunakan (Basrowi dan Suwandi, 2008). Dalam penelitian ini peneliti memilih informan dengan pertimbangan khusus, karena informan dalam penelitian ini terbatas pada jenis orang tertentu yang dapat memberikan informasi sesuai dengan tujuan penelitian. Subjek dalam penelitian ini meliputi individu-individu yang terlibat dalam konflik, ketua adat, mantan ketua adat, staf kelurahan, ninik mamak, tetangga keluarga yang berkonflik, ketua RW, dan ketua RT.

Observasi yang dilakukan dalam penelitian ini adalah observasi partisipasi pasif. Observasi ini bersifat open-ended, di mana peneliti mengajukan pertanyaan-pertanyaan umum kepada informan yang memungkinkan informan bebas memberikan pandangan-pandangan mereka (Creswell, 2009). Perihal pokok yang diobservasi (diamati) dalam penelitian ini adalah berbagai tindakan yang dilakukan oleh individu-individu dari keluarga yang berkonflik. Pengamatan ini dimulai dari kondisi dan situasi dalam keluarga setelah terjadi konflik, misalnya hubungan antara kakak dengan adik, antara paman dengan keponakannya dan bibi dengan keponakannya. Peneliti berada atau datang ke lokasi penelitian di Kelurahan Pulau Temiang, namun peneliti bukan bagian dari keluarga-keluarga yang berkonflik. Observasi pada penelitian ini merupakan kegiatan mengamati konsekuensi dari konflik yang terjadi dalam keluarga akibat memperebutkan harta warisan, dengan prosedur mengamati kegiatan sehari-hari individuindividu dalam keluarga yang terlibat konflik harta warisan.

Selanjutnya peneliti melakukan wawancara dengan pihak-pihak menyaksikan penyelesaian konflik harta warisan di Pulau Temiang, seperti sekretaris lurah dan para staf kelurahan, ketua adat dan mantan ketua adat, ketua RW dan ketua RT. Selanjutnya, wawancara dengan individu-individu yang terlibat dalam tersebut. Wawancara yang dilakukan adalah wawancara mendalam (in-depth interview) (Burhan Bungin, 2003).

Supaya data penelitian akurat, valid dan sah, maka dilakukan trigulasi data. Triangulasi sumber dalam penelitian ini dilakukan dengan membandingkan data yang diperoleh melalui wawancara, observasi dan dokumentasi. Apabila dari ke tiga teknik pengumpulan data tersebut

\section{Culture \& Society: Journal of Anthropological Research Vol. 1, No. 1, Th. 2019}


menghasilkan data yang berbeda-beda, maka penulis melakukan diskusi lebih lanjut dengan informan yang bersangkutan untuk memperoleh data yang dianggap valid (Sugiyono, 2005). Oleh sebab itu, jika terdapat perbedaan data yang diperoleh melalui observasi, dokumentasi dan wawancara, maka data yang dianggap valid yaitu data yang diperoleh dari hasil observasi dan dokumentasi. Pemilihan tersebut dilakukan karena data yang didapatkan dari hasil wawancara disampaikan informan terkadang dipengaruhi oleh opini yang bersangkutan maupun situasi saat melakukan wawancara, sehingga informan tidak menyampaikan informasi yang sebenarnya. Teknik analisis yang dirujuk adalah teknik analisis data dari Miles dan Huberman. Data dianggap valid, apabila dalam pengumpulan data sudah tidak ada lagi ditemukan variasi informasi, maka peneliti tidak perlu lagi mencari informan baru dan proses pengumpulan data dianggap selesai.

\section{Hasil dan Pembahasan}

Pada umumnya, harta yang diperebutkan dalam masyarakat Pulau Temiang adalah harta tidak bergerak yaitu tanah. Tanah sangat berharga bagi masyarakat agraris, karena itu setiap orang ingin memilikinya. Tanah merupakan salah satu simbol dari kekayaan, maka tidak asing lagi jika selalu terjadinya konflik dalam hal perebutan hak atas tanah ( Syatri Syatri, Fitri Eriyanti, Erianjoni Erianjoni, 2018). Setelah harta warisan itu diadakan pembagian, maka masing-masing waris dapat menguasai dan memiliki bagian harta warisannya untuk diusahakan, dinikmati ataupun dialihkan kepada sesama waris, maupun anggota kerabat lainnya. Kelemahan dari sistem ini adalah pecahnya harta warisan berkonsekuensi kepada merenggangnya tali kekerabatan. Pewarisan dengan sistem ini dapat menjurus kepada sifat individualisme dan materialisme yang menyebabkan timbulnya perselisihan-perselisihan antara anggota keluarga pewaris.

\section{Faktor Penyebeb Terjadinya Konflik Harta Warisan}

Dari 20 kasus konflik harta warisan, 9 (sembilan) kasus berakar dari dominasi oleh pihak tertua dan 11 kasus merupakan kecemburuan terhadap perempuan bungsu. Baginya yang terpenting adalah dia ingin menguasai harta orangtuanya. Konflik dalam keluarga dapat terjadi karena adanya ketidaksetujuan atau perilaku oposisi antara anggota keluarga (Riadi dan Nurdin, 2008). Perselisihan yang terjadi dalam masyarakat Pulau Temiang berawal pada pembagian harta yang sudah diwasiatkan terlebih dahulu oleh orang tua dari ahli waris. Proses pewarisan dilakukan semasa pewaris masih hidup maka dapat dilakukan dengan cara berpesan, penerusan, pengalihan, berwasiat, dan beramanat (Absyar Surwansyah, 2005). Berikut akan dijelaskan yang menjadi penyebab konflik harta warisan dalam masyarakat Pulau Temiang.

\section{Dominasi dari Saudara Sulung}

Sebelum pewaris meninggal dunia, mereka menyetujui begitu saja pembagian yang dilakukan tersebut. Wasiat dari orangtua biasanya berupa rumah, perabot dan pekarangan diberikan kepada anak perempuan bungsu, tanah, kebun karet, kebun sawit dan kebun duku diwasiatkan berdasarkan latar belakang ekonomi masing-masing ahli waris seperti kaya atau miskin, cacat atau tidak beserta bagaimana konstribusinya terhadap orangtuanya seperti banyak membantu atau tidak, peduli atau tidak dengan orangtuanya. Pembagian harta yang mereka sepakati adalah dengan mengutamakan pertimbangan-pertimbangan, seperti keadaan istimewa terhadap masing-masing saudara.

Pak AN adalah anak tertua dari 9 (sembilan) orang bersaudara, Laki-laki 5 (lima) orang dan perempuan 4 (empat) orang. Harta kekayan orangtuanya adalah 5 (lima) hektar kebun karet, 2 (dua) hektar kebun sawit, 200 meter tanah perumahan/tanah kosong, termasuk rumah orangtuanya sekarang. Pembagian harta warisan dengan rincian yaitu: (1) AN, 1 (satu) hektar kebun karet; (2) DN, MZ, WD, SP, masing-masing mandapatkan 1 (satu) hektar kebun karet

\section{Culture \& Society: Journal of Anthropological Research Vol. 1, No. 1, Th. 2019}


dan sawit; (3) MR, LB, NH, LN merupakan anak perempuan dan mendapatkan tanah perumahan seluas 200 meter dibagi sebanyak 4 (empat) orang. Selain itu, anak perempuan ini juga mendapatkan 2 (dua) hektar kebun karet yang yang dibagi sebanyak 4 (empat) orang.

Persoalan dalam pembagian harta warisan ini adalah tuntutan Pak AN yang mengatakan bahwa ini tidak adil karena dia adalah anak tertua tentunya lebih banyak berkonstribusi terhadap orangtuanya tetapi dia tidak mendapatkan bagian lebih. Pak AN mempermasalahkan semua adik-adiknya tidak memberikan bagian tanah/kebun karet sesuai dengan susah payah dalam pembukaan lahan kebun karet tersebut.

Ketika pewaris masih hidup, harta yang dibagikan tersebut belum dimiliki secara mutlak oleh ahli waris, melainkan baru berupa pemilikan sementara untuk pemeliharaan harta berupa tanah pertanian, dan tanaman seperti duku dan kelapa. Hasil dari pertanian dan buah-buahan dibagi dengan pewaris sesuai dengan pendelegasian oleh pewaris sendiri. Sistem seperti ini disepakati oleh anggota keluarga untuk biaya hidup masa senja pewaris. Pewaris menginginkan pada masa tuanya tetap ingin dihormati selayaknya orang tua. Selain itu agar kewibawaan sebagai orang tua tetap terjaga, tidak menggantungkan hidup kepada anaknya melainkan dari hasil harta pewaris sendiri.

Masyarakat Pulau Temiang adalah masyarakat yang mata pencahariannya bertani dan berkebun. Adapun tanaman kebun itu adalah karet dan sawit. Harta yang diperebutkan oleh keluarga dalam masyarakat Pulau Temiang adalah kebun karet, kebun sawit, rumah dan tanaman-tanaman.

\section{Kecemburuan Terhadap Saudara Perempuan Bungsu}

Hukum adat yang berlaku dalam masyarakat tersebut bahwa anak perempuan bungsu akan mendapatkan harta warisan berupa tanah perkarangan dan rumah beserta isinya. Rumah yang didapatkan tersebut adalah rumah peninggalan orang tuanya. Anak perempuan bungsu yang masih berusia remaja ke bawah juga tetap tinggal di rumah orangtuanya dan mendapatkan rumah tersebut. Rumah diberikan kepada anak perempuan bungsu karena biasanya dia akan hidup bersama dan tinggal bersama dengan orangtuanya hingga meninggal dunia.

Dari 20 kasus harta warisan dalam masyarakat Pulau Temiang, 11 kasus justru berakar dari kecemburuan terhadap perempuan bungsu. Selama tinggal bersama orang tuanya, dia mengurus orangtuanya ketika sakit dan menemaninya hingga akhir hayat. Untuk itu, sebagai imbalan karena dia telah menjaga orang tuanya maka dia berhak mendapatkan rumah beserta isinya berikut pekarangan rumah tersebut. Setelah orang tuanya meninggal, terjadilah kecemburuan saudara-saudara yang lain karena perempuan ini mendapatkan rumah yang dibuat oleh orangtuanya. Mereka berpikir sang adik ini tidak lagi bersusah payah membuat rumah, mudah saja dia mendapatkan rumah beserta isinya dan pekarangannya.

Kecemburuan yang terjadi antara anggota keluarga membuat tejadinya perpecahan dan perselisihan. Keluarga-keluarga dalam masyarakat Pulau Teming berkonflik akibat memperebutkan harta yang sudah diberikan hak atas kepemilikannya kepada saudaranya. Kepemilikan tersebut diberikan atas dasar pertimbangan-pertimbangan sesuai dengan keadaan ahli waris. Anak perempuan bungsu yang tinggal di rumah orangtuanya dan mendapatkan rumah tersebut seringkali dipermusuhkan karena tidak adanya rasa keadilan antara masingmasing ahli waris.

\section{Proses dan Hasil Solusi Konflik}

\section{Proses Solusi Konflik}

Berdasarkan dokumen surat keputusan kesepakatan damai antara kedua belah pihak, terlihat bahwa dalam proses penyelesaian konflik banyak tokoh masyarakat ikut terlibat. Hal ini dibuktikan dengan daftar absen saat musyawarah yang biasanya dilaksanakan di rumah ketua RW. Solusi konflik difokuskan pada sumber konflik antara kedua pihak, agar mereka bersama-

\section{Culture \& Society: Journal of Anthropological Research Vol. 1, No. 1, Th. 2019}


sama mengidentifikasi isu-isu yang lebih nyata. Jika kedua pihak tidak setuju atas isu yang sudah digariskan, maka kita membutuhkan negosiator. Seorang negosiator (fasilitator) itu penting ketika konflik semakin luas dan tidak dapat ditekan, karena sudah mengandung emosi dan ancaman.

Permasalahan yang terjadi antar keluarga diselesaikan dengan cara musyawarah melalui mediasi. Hal ini sesuai dengan metode penyelesaian konflik yaitu akomodasi. Akomodasi yaitu pihak yang berkonflik lebih suka pihak lain yang mengontrol dan tertarik dengan informasi dan persetujuan pihak lain (Liliweri, 2005). Ketika warganya berkonflik, maka tokoh-tokoh masyarakatnya yang mempunyai tanggungjawab sebagai kontrol sosialnya.

Dalam hal penyelesaian konflik harta warisan ini yang berperan sebagai penengah atau mediatornya adalah ketua adat, tokoh-tokoh masyarakat, dan pihak terkait lainnya. Sesuai dengan proses resolusi dengan metode penyelesaian konflik oleh Liliweri yaitu pada metode kompromi. Sama halnya dengan metode akomodasi, metode kompromi juga mengandalkan penengah atau mediator sebagai pengontrol konflik. Pada konflik ini mediator yang sangat berperan adalah ketua adat Pulau Temiang.

Sesuai hasil studi dokumentasi yang dilakukan di lapangan bahwa dalam surat keputusan damai antara pihak-pihak yang terlibat dalam konflik harta warisan terlampir daftar hadir staf kelurahan, ketua adat, ninik mamak, ketua RT dan RW. Sesuai dengan yang dikatakan oleh Liliweri dalam metode penyelesaian konflik yaitu pada metode kolaborasi/ pemecahan masalah dimulai dengan sebuah strategi mengumpulkan informasi, berdialog atau musyawarah, serta mencari alternatif (Liliweri, 2005). Musyawarah yang diadakan di rumah ketua RW ini termasuk pada metode penyelesaian konflik pada strategi kolaborasi, karena dilakukan sesuai dengan tata caranya yaitu mengumpulkan informasi, berdialog/musyawarah, serta mencari alternatif.

\section{Hasil Solusi Konflik}

Berikut hasil keputusan tertulis yang telah disepakati oleh pihak yang berkonflik:

a. Tidak membuat keributan lagi antar anggota keluarga sehingga mengganggu ketertiban masyarakat.

b. Pihak pertama setuju bahwa pihak kedua memiliki hak penuh terhadap tanah tersebut.

c. Pihak pertama dan pihak kedua tidak lagi mengungkit-ngungkit tanah tersebut dikemudian hari.

d. Kasus ini tidak dilanjutkan ke LAM Tebo maupun ke pengadilan negeri.

Penyelesaian konflik melalui musyawarah keluarga ini seringkali tidak sampai kepada keputusan yang final. Dikatakan demikian, karena setelah kesepakatan damai konflik laten (tersembunyi) tetap tumbuh dikalangan keluarga/kerabat. Keputusan yang telah disepakati, tidak mampu mengikat dan menyelesaikan perselisihan antara kedua belah pihak. Hal ini dibuktikan dengan tidak saling sapaan, jika ada acara keluarga salah satu pihak dan saudara lain yang mendukung pihak tersebut juga tidak ikut serta dalam acara tersebut. Keluarga-keluarga yang berkonflik, mengingkari keputusan yang telah mereka sepakati sebelumnya. Keputusan dibuat atas kesepakatan kedua belah pihak dan diketahui oleh lurah. Beberapa faktor yang menyebabkan konflik terus berlanjut/konflik tersembunyi adalah sebagai berikut:

\section{Pelanggaran Terhadap Hasil Putusan Musyawarah tidak Disertai Sanksi yang Tegas}

Berdasarkan surat keputusan hasil musyawarah dapat dilihat bahwa tidak ada sanksi yang tegas apabila terjadi pelanggaran terhadap keputusan msuyawarah tersebut. Seharusnya, dalam poin-poin keputusan itu disebutkan jika dilanggar maka ada konsekuensinya. Namun, jika keluarga sudah sepakat maka akan dikeluarkan surat keputusan damai. Keluarga-keluarga tersebut mencapai kata sepakat karna tidak ingin berdebat terus menerus dalam forum musyawarah.

\section{Culture \& Society: Journal of Anthropological Research Vol. 1, No. 1, Th. 2019}




\section{Penyelesaian Konflik ke Pengadilan Negeri}

Penyelesaian konflik pada tingkat desa seringkali tidak sampai kepada keputusan yang final. Dikatakan demikian, karena setelah kesepakatan damai, konflik tersembunyi tetap tumbuh dikalangan orang-orang yang bersaudara (kerabat). Masyarakat Pulau Temiang melakukan penyelesaian perkara warisan ini ke jalur formal yaitu Bapak Hirul, sementara yang lain melakukan penyelesaian konflik hanya melalui musyawarah dalam keluarga. Masyarakat setempat menilai penyelesaian ke jalur formal itu membutuhkan biaya tinggi. Oleh sebab itu, mereka merasa enggan berurusan dengan jalur formal tersebut. Masyarakat lebih memilih meminta bantuan kepada lembaga pengadilan desa dan lembaga pengadilan adat, jarang sekali menyelesaikan konflik harta warisan sampai kepada tingkat pengadilan tertinggi seperti LAM Tebo Jambi dan pengadilan negeri. Menyelesaikan kasus ke pengadilan bisa memakan biaya dengan biaya awal mendekati Rp. 2.000.000,', belum lagi lokasi kabupaten jauh dari Kelurahan Pulau Temiang dan harus mengeluarkan biaya untuk datang menghadiri pengadilan tersebut. Oleh sebab itu, dari pada menghabiskan uang lebih baik mereka menyelesaikan konflik tersebut melalui musyawarah keluarga.

\section{Kesimpulan}

Masyarakat Pulau Temiang mempunyai aturan adat dalam membagi harta warisan yaitu berdasarkan pertimbangan-pertimbangan dengan melihat latar belakang kondisi ekonomi dan konstribusi dari masing-masing ahli waris terhadap orangtua. Adanya aturan adat yang demikian membuat masyarakat salah menerapkan aturan yang ada itu. Adapun penyebab terjadinya konflik dalam pembagian harta warisan adalah karena dominasi dari saudara sulung dan kecemburuan terhadap saudara perempuan bungsu. Oleh sebab itu, terjadilah konflik dalam keluarga pada masyarakat Pulau Temiang.Proses solusi konflik antar keluarga ini diselesaikan dengan bantuan mediator yaitu ketua adat Pulau Temiang. Resolusi konflik ini menghasilkan keputusan tertulis yaitu sebuah kesepakatan damai yang disepakati oleh kedua belah pihak dan diketahui oleh lurah setempat. Adapun penyelesaian konflik dilakukan pada tingkat desa yang cenderung menyisakan permasalahan-permasalahan yang berkepanjangan sehingga muncul kembali konflik laten (tersembunyi). Hal ini disebabkan karena tidak adanya sanksi yang tegas terhadap keputusan yang telah diberikan. Umumnya, kasus-kasus konflik tersebut juga jarang yang diselesaikan pada lembaga formal seperti pengadilan negeri. Hal ini disebabkan karena biaya yang terlalu mahal. Akibatnya, pihak-pihak yang terlibat konflik hanya menerima saja hasil keputusan meskipun masih menyisakan permasalahan-permasalahan yang berkepanjangan.

\section{Daftar Pustaka}

Absyar Surwansyah. (2005). Suatu Kajian Tentang Hukum Waris Adat Masyarakat Bangko Jambi. Universitas Diponegoro.

Arwin Rio Saputra. Persepsi Masyarakat Semende terhadap Pembagian Harta Warisan dengan Sistem Tunggu Tubang. Jurnal Sosiologi, 15(1), 51-62.

Basrowi dan Suwandi. (2008). Memahami Penelitian Kualitatif. Jakarta: Rineka Cipta.

Burhan Bungin. (2003). Analisis Data Penelitian Kualitatif. Jakarta: PT. Raja Grafindo Persada.

Creswell, J. W. (2009). Research Design Pendekatan Penelitian Kualitatif, Kuantitatif dan Mixed (P. A. Fawaid, Ed.). Yogyakarta: Pustaka Pelajar.

Dedi Agus Riadi dan Bartoven Vivit Nurdin. (2008). Marga Pugung Tampak: Studi Konflik Keluarga Dalam Sistem Pewarisan pada Masyarakat Pesisir Utara Lampung. Jurnal Sosiologi, 18(2), 95-103.

Syatri Syatri, Fitri Eriyanti, Erianjoni Erianjoni. (2018). Faktor Sosio Budaya yang Mempengaruhi Konflik Tanah dalam Masyarakat Minangkabau (Studi Sengketa Konflik

\section{Culture \& Society: Journal of Anthropological Research Vol. 1, No. 1, Th. 2019}


Antara Suku Tanjung Manggopoh dengan Nagari Tiku V Jorong Kabupaten Agam) Socio Cultural Factors Affecting The Land Conflict In The Minangkabau Comm. Jurnal Sosiologi Pendidikan Humanis, 2(2), 110-118.

Iwan. (2015). Mekanisme Penyelesaian Sengketa Tanahmelalui Adat Padamasyarakat Desa Teluk Pandak Kecamatan Tebo Tengah Kabupaten Tebo Provinsi Jambi. STKIP PGRI Sumatera Barat.

Lexi J. Moleong. (2000). Metodologi Penelitian Kualitatif. Bandung: Remaja Rosdakarya.

Liliweri, A. (2005). Prasangka dan Konflik. Yokyakarta: PT. LkiS.

Mohamad Imam Suhadak. (2015). Perebutan Harta Waris antara Anak Piara dengan Ibu Piara Menurut Hukum Adat Osing pada Masyarakat Kemiren Kabupaten Banyuwangi. Universitas Jember. Jember.

Saputri, A., Thahar, H. E., \& Hayati, Y. (2016). Konflik Sosial pada Novel Warisan. Jurnal Pendidikan Bahasa Dan Sastra Indonesia, 5 (September), 52-58.

Sugiyono. (2005). Memahami Penelitian Kualitatif. Bandung: Alfabeta.

Saputri. 2016. Konflik Sosial pada Novel Warisan Karya Chairul Harun. Jurnal. Padang: Universitas Negeri Padang.

Titik Khumairoh. (2011). Penjualan Harta Warisan yang Belum dibagi dalam Tinjauan Hukum Islam dan Hukum Perdata. STAIN Salatiga. 